\title{
PERSEPSI PEMAKAI TERHADAP KUALITAS PELAYANAN TERBITAN BERKALA DI PERPUSTAKAAN PASCASARJANA UGM
}

\author{
Oleh: Supriyono * dan Umar Sidik ** \\ Intisari
}

Penelitian ini mendeskripsikan Persepsi Pemakai Terhadap Kualitas Pelayanan Terbitan Berkala di Perpustakaan Pascasarjana Universitas Gadjah Mada. Permasalahan yang dikaji dalam skripsi ini adalah persepsi pemakai terhadap kualitas layanan terbitan berkala di Perpustakaan Pascasarjana UGM. Tujuan penelitian ini untuk mengetahui persepsi pemakai terhadap pelayanan terbitan berkala di Perpustakaan Pascasarjana Universitas Gadjah Mada. Dalam pembahasan ini digunakan teori servqual dari Parasuraman. Sementara analisisnya dengan menggunakan lima dimensi kualitas layanan yaitu dimensi bukti fisik, dimensi keandalan, dimensi daya tanggap, dimensi jaminan, dan dimensi empati. Penelitian ini menggunakan metode deskriptif kuantitatif dengan maksud untuk menggambarkan persepsi pemakai terhadap kualitas pelayanan terbitan berkala. Pengumpulan data dengan menggunakan angket dan wawancara. Responden penelitian ini adalah mahasiswa S2 sejumlah 100 responden.

Berdasarkan hasil olah data masing-masing variabel dimensi persepsi pemakai terhadap pelayanan terbitan berkala sebagai berikut: variabel dimensi fisik sebesar 4,18 dimensi kehandalan sebesar 3,98 dimensi daya tanggap sebesar 4,11 dimensi jaminan sebesar 3,72 dimensi empati sebesar 4,18 Ada dua dimensi yang paling rendah nilainya yaitu dimensi kehandalan sebesar 3,98 dan dimensi jaminan sebesar 3,72 Mengingat nilai total rata-rata variabel persepsi pemakai adalah 4,03, maka persepsi pemakai terhadap kualitas layanan terbitan berkala di Perpustakaan Pascasarjana Universitas Gadjah Mada adalah baik.

Kata kunci : Persepsi Pemakai, Kualitas Pelayanan, Terbitan Berkala

\begin{abstract}
This research is to describe the user perception of the serials service quality at the postgraduate library Gadjah Mada University. The problem discussed in this research is the user perception of serials service quality at the postgraduate library Gadjah Mada University. The research aims to know the user perception of serials service quality at the postgraduate library Gadjah Mada University. The research employs the servqual theory adapted from Parasuraman. The theory uses five dimensions consisting of physical proof, realibility, responsiveness, guarantee, and empathy and are used to analyze the data collected. The research uses a quantitative descriptive method to describe user perception of serials service quality at the postgraduate library Gadjah Mada University. Research data were collected by using questionnaire and interview and the respondents used are 100 postgraduate students.

The result of the research shows that each dimension variable will be seen in the following: physical dimension is 4,18; reliability is 3,98; responsiveness is 4,11; guarantee is 3,72; and empathy is 4,18. There are two dimensions which are the lowest dimensions score i.e. reliability 3,98; and guarantee 3,72. Since the grand mean of user perception is 4,03, we can conclude that user perception of serials service quality at the postgraduate library Gadjah Mada University is good enough.
\end{abstract}

Key words : User Perception, Service Quality, Serials

*) Pustakawan UGM

**) Peneliti Balai Bahasa Yogyakarta 


\section{PENDAHULUAN}

Perpustakaan perguruan tinggi merupakan unsur penunjang perguruan tinggi, bersama-sama dengan unsur penunjang lainnya berperan serta melaksanakan kegiatan demi tercapainya visi dan misi perguruan tinggi. Peran perpustakaan perguruan tinggi adalah sebagai pengumpul, penyusun, dan pemelihara informasi untuk menunjang Tri Dharma perguruan tinggi.

Perpustakaan Pascasarjana UGM sebagai pusat penyimpanan dan penyebaran informasi ilmiah, merupakan bagian yang penting bagi sivitas akademika Universitas Gadjah Mada. Keberadaan Perpustakaan Pascasarjana di Universitas Gadjah Mada dimaksudkan untuk menunjang kelancaran pendidikan dan pengajaran penelitian bagi mahasiswa dan pengajar program Pascasarjana UGM. Dukungan perpustakaan kepada universitas ini diberikan dalam bentuk penyediaan informasi bagi sivitas akademika dan masyarakat yang membutuhkan. Kualitas pelayanan sering dihubungkan dengan persepsi konsumen. Oleh karena itu untuk memberikan pelayanan yang berkualitas, pihak pengelola Perpustakaan Pascasarjana UGM perlu selalu memahami pengguna dan harapan serta situasi yang ada. Menurut Teas dalam Masruri, 2004: 5 menyatakan bahwa ada dua faktor yang dapat mempengaruhi kualitas pelayanan dilihat dari sisi pengguna, yaitu expected service dan perceived service. Jika pelayanan yang diterima sesuai dengan yang mereka harapkan, maka pelayanan dinilai berkualitas. Bila pelayanan yang diterima melebihi apa yang diharapkan pengguna, maka pelayanan dinilai sangat ideal. Tetapi bila pelayanan yang diterima lebih rendah dari apa yang diharapkan, pelayanan tersebut dinilai buruk dan tidak berkualitas. Dengan demikian yang paling utama yang harus dilakukan adalah kerja sama yang baik antara pengguna dengan perpustakaan. Sebab perpustakaan tidak dapat berjalan sendin menghadapi masalah kualitas pelayanan. Kualitas merupakan salah satu faktor utama dalam menentukan pemilihan pelanggan. Kepuasan pelanggan akan tercapai apabila kualitas produk yang diberikan sesuai dengan kebutuhannya.
$\mathrm{Hal}$ yang penting dari terbitan berkala adalah terbit secara terus - menerus dan topik tulisan yang berbeda dalam setiap kali terbit. Sehingga informasi yang terkandung merupakan informasi yang terbaru. Hal ini tidak bisa dilakukan oleh penerbitan buku teks karena mempunyai jangka waktu yang cukup lama antara penemuan ide, penulisan dan saat terbit. Kemutakhiran informasi dalam terbitan berkala merupakan hal yang penting bagi pengguna perpustakaan. Oleh sebab itu, perpustakaan dituntut untuk menyediakan informasi yang cukup lengkap dan mutakhir. Namun menurut Purwanti (1997) dalam Diani (1997: 4) untuk subjek - subjek tertentu kemutakhirannya bersifat relatif. Pada umumnya jenis - jenis bahan pustaka yang terdapat dalam koleksi terbitan berkala adalah berupa majalah, warta, serial, buku tahunan, laporan hasil kongres, buku pegangan dengan suplemen yang menyertainya, koran, buletin pamflet, abstrak, laporan sejarah (annual), leaflet, jurnal dan brosur (Lasa HS, 1991:2). Namun dalam penelitian ini yang akan dikaji adalah terbitan berkala yang berbentuk majalah ilmiah dan jurnal.

Sementara harga majalah semakin lama semakin mahal sehingga mengakibatkan perpustakaan berhenti berlangganan majalah tersebut, anggaran tidak selalu mampu mengikuti kenaikan harga majalah dari tahun ke tahun yang mengakibatkan penyusutan langganan beberapa judul majalah. Bagi beberapa pihak kondisi ini mungkin dianggap tidak penting, namun kalau diingat bahwa majalah adalah sebagai sarana informasi mutakhir, untuk bidang pengetahuan dan teknologi, berkurangnya judul majalah berarti semakin sedikit informasi yang diperoleh.

Perpustakaan Pascasarjana UGM menerapkan sistem layanan terbuka (open acces) layanan terbitan berkala. Salah satu tujuan diterapkannya sistem ini adalah agar semua koleksi yang tersedia dapat dimanfaatkan secara optirnal. Adapun jasa layanan koleksi terbitan berkala yang tersedia di Perpustakaan Pascasarjana berupa majalah/jurnal terbaru maupun terjilid tersedia di lantai III. Layanan informasi majalah/jurnal dalam bentuk tercetak, digital dan database online dipandu oleh operator 
bagian layanan majalah/jurnal. Fasilitas untuk jumal online ini hanya dapat diakses di lingkungan UGM seperti Proquest dan EBSCO. Juga tersedia katalog online untuk memudahkan pengguna mencari informasi yang dibutuhkan.

\section{Landasan Teori}

\section{Pengertian Persepsi}

Persepsi merupakan suatu proses yang didahului oleh penginderaan. Penginderaan adalah merupakan suatu proses diterimanya stimulus oleh individu melalui alat penerima yaitu indera. Namun proses tersebut tidak berhenti disitu saja. Pada umumnya stimulus tersebut diteruskan oleh syaraf ke otak sebagai pusat susunan syaraf, dan proses selanjutnya merupakan proses persepsi (Walgito,2003:45). Kemudian Pasuraman, Zeithaml dan Berry (1988 :16) mendefinisikan persepsi kualitas pelayanan sebagai keseluruhan pertimbangan(judgment) atau sikap yang berhubungan dengan keunggulan pelayanan atau jasa. Persepsi kualitas adalah tingkat dan arah ketidaksesuaian/perbedaan persepsi konsumen dan harapan konsumen. Dalam literatur pemasaran jasa, persepsi (perception = p) didefinisikan sebagai kepercayaan konsumen yang berhubungan dengan jasa yang diterima (Parasuraman,Zeithaml) \& Berry 1988: 12) Harapan (expection = E) didefinisikan oleh peneliti yang sama sebagai keinginan atau kemauan konsumen seperti apa yang mereka rasakan terhadap jasa yang seharusnya ditawarkan atau diberikan kepada mereka, bukan pada apa yang akan ditawarkan kepada mereka.

\section{Mahasiswa sebagai Pemakai Perpustakaan}

Pada tinjauan ini mahasiswa sebagai pemakai perpustakaan.Menurut SulistyaBasuki (1994:199) pemakai perpustakaan adalah orang yang ditemuinya tatkala orang tersebut memerlukan data primer atau menghendaki penelusuran bibliografi. Sedangkan Rosyadi (2002:4) mendefinisikan pemakai sebagai setiap individu dalam masyarakat, dalam pengertian semua anggota masyarakat memiliki kebebasan dan kesempatan yang sama untuk menggunakan
perpustakaan.Tapi perpustakaan yang berada di bawah lembaga tertentu, mendefinisikan pemakai sesuai dengan misi dan tujuan masingmasing. Untuk Perpustakaan Sekolah Pascasarjana UGM membatasi pemakainya pada anggota sivitas akademika didalam kampusnya yang terdiri didalam mahasiswa, dosen, peneliti. Masyarakat di luar kampus boleh memanfaatkannya dengan dikenai aturan khusus. Pemakai yang dimaksud penelitian ini dibatasi pada mahasiswa yang menjadi anggota Perpustakaan sekolah Pascasarjana UGM

3. Pelayanan Terbitan berkala.

1) Pelayanan Informasi Terseleksi atau Selection Dessemination Information, yaitu pelayanan perpustakaan menyediakan informasi yang sesuai dengan minat bidang ilmu dimana pemakai yang menjadi pelanggan

2) Pelayanan Informasi mutakhir adalah pelayanan perpustakaan menyediakan informasi terbaru dan sering kali tanpa batas-batas subjek tertentu selain hanya kemuthakiran itu sendiri. Ketika melakukan SDI atau CAS diperlukan waktu yang cukup banyak dan kesabaran yang tinggi.Dalam penelusuran terutama SDI harus melakukan pemilihan bahan pustaka secara teliti sesuai profil pengguna.

3) Pelayanan Informasi Cepat adalah layanan yang dikhususkan untuk menyajikan informasi artikel terbaru secara cepat, memberikan informasi segera kepada pengguna mengenai isi koleksi yang baru saja diterima

4) Layanan informasi elektronik perpustakaan memberikan layanan informasi akses ke dalam sumber elektronik baik yang disediakan oleh komputer melalui media floppy disc. Pengelola dapat menyediakan fasilitas komputer yang terhubung ke dalam server sumber elektronik melalui email (Arif, 2006: 5)

\section{Pengertian Kualitas}

Untuk memahami quality service, harus dipahami pengertian kualitas itu sendiri terlebih dahulu. Menurut Tjiptono (1995:4) pengertian kualitas sangat sukar didefinisikan. Orang akan 
mengetahuinya jika melihat dan merasakannya. Sebagian orang mengaitkan kualitas dengan produk atau jasa, tetapi sebenarnya kualitas lebih dari itu. Menurutnya kualitas jasa termasuk proses, lingkungan dan manusia. Hal ini tampak jelas dalam definisi bahwa kualitas merupakan suatu kondisi dimana yang berhubungan dengan produk, jasa manusia, proses, dan lingkungan yang memenuhi atau melebihi harapan.

Kualitas sering diungkapkan dalam beberapa definisi dan sudut pandang pemakai. Kualitas sering diasosiasikan dengan value, userfulness ataupun harga. Dan nilai atas kualitas tersebut digambarkan atas nilai utility dan manfaatnya sehingga pemakai pada akhirnya akan menerimanya sebagai sesuatu yang memuaskan. Sedangkan dari sisi penyedia kualitas seringkali diterapkan dengan membandingkan antara standar yang spesifik, perfomance dan konfirmitas yang aktual.

Tjiptono (1995:3) mengungkapkan bahwa tidak ada definisi mengenai kualitas yang dapat diterima semua orang. Namun demikian ada elemen yang sama dalam berbagai definisi yang ada diantaranya adalah :

1. Kualitas berkaitan dengan memenuhi atau melebihi harapan konsumen

2. Kualitas mencakup produk, jasa, manusia, proses dan lingkungan

3. Kualitas adalah kondisi yang selalu berubah

Sedangkan kualitas pelayanan menurut Lovecock (1988) dalam Riyanto, 2001:14) adalah tingkat keunggulan yang diharapkan dan pengendalian atau tingkat keunggulan tersebut untuk memenuhi pemakai. Dengan demikian ada faktor utama yang mempengaruhi kualitas pelayanan yaitu Expected service dan perceived service. Definisi sejalan dengan yang dikemukakan oleh Parasuraman, Zeithmal dan Berry (1985:41) bahwa jika pelayanan yang diterima atau yang dirasakan (preceived service) sesuai dengan yang diharapkan, maka kualitas pelayanan dipersepsikan sebagai kualitas yang ideal. Sebaliknya jika kualitas pelayanan yang diterima lebih rendah dari pada yang diharapkan, maka kualitas pelayanan tergantung pada kemampuan penyedia jasa dalam memenuhi harapan pemakai secara konsisten.

\section{Dimensi Kualitas Layanan}

Kualitas suatu produk baik berupa barang maupun jasa perlu ditentukan melalui dimensi-dimensinya. Beberapa pakar pemasaran seperti Parasuraman, Zeithmal dan Berry (1985) dalam Tjiptono (1995:27) melakukan beberapa penelitian khusus terhadap beberapa jenis jasa dan mengidentifikasi faktor yang memengaruhi kualitas layanan yang biasa disebut sebagai dimensi kualitas. Dalam perkembangannya, dimensi kualitas yang semula berjumlah sepuluh dirangkum menjadi lima dimensi pokok, sebagai berikut :

1. Bukti Fisik (tangible), meliputi fasilitas fisik, peralatan pegawai dan sarana komunikasi

2. Keandalan (Reliability) berupa kemampuan memberikan pelayanan yang dijanjikan dengan segera, akurat, dan memuaskan.

3. Daya Tanggap (Responsivness) yaitu keinginan para staf untuk membentuk para pemakai dan memberikan pelayanan dengan tanggap.

4. Jaminan (Assurance) yaitu mencakup pengetahuan, kemapuan para staf memliki ketrampilan, menunjukkan kesopanan dan percaya diri dari.

5. Empati (Emphaty) meliputi kemudahan dalam melakukan hubungan komunikasi yang baik, perhatian pribadi akan kebutuhan dan keinginan pemakai dan meyakinkan pengguna bahwa perusahaan menyediakan pelayanan untuk pelanggannya.

Menurut Durianto (2004: 40) dimensi kualitas layanan adalah kualitas layanan (service quality), sangat bergantung pada tiga hal, yaitu sistem, teknologi, dan manusia. Faktor manusia memegang kontribusi terbesar sehingga kualitas layanan relatif lebih sulit ditiru dibandingkan kualitas produk dan harga. Salah satu konsep kualitas layanan yang populer adalah Servqual. Berdasarkan konsep ini, kualitas layanan diyakini memiliki lima dimensi, yaitu reliability, responsiveness, asurance, empaty, dan tangible.

Dimensi pertama kualitas layanan adalah bukti fisik (tangible), menimbang bahwa suatu 
layanan tidak bisa dilihat, dicium, dan diraba. Maka aspek tangible menjadi penting sebagai ukuran pelayanan. Sebagai gambaran, pelanggan memberikan penilaian yang baik apabila perpustakaan dilengkapi dengan peralatan yang canggih. Selain gedung dan peralatan, pelanggan akan menilai tampilan fisik karyawan. Dimensi ini umumnya lebih penting bagi pelanggan baru.

Dimensi kedua kualitas layanan adalah keandalan, yaitu dimensi yang mengukur keandalan perpustakaan dalam memberikan pelayanan kepada pelanggannya. Dibandingkan empat dimensi kualitas layanan yang lain, dimensi ini dipersepsi paling penting dalam berbagai industri jasa. Dimensi ini memiliki dua aspek, yaitu kemampuan perpustakaan memberikan pelayanan sesuai yang dijanjikan dan seberapa jauh perpustakaan mampu memberikan pelayanan yang akurat.

Dimensi ketiga kualitas layanan adalah daya tanggap (responsiveness). Harapan pelanggan terhadap kecepatan pelayanan tidak akan cenderung meningkat dari waktu ke waktu. Perlu diingat bahwa keinginan pelanggan pada satu waktu bisa dipersepsi berbeda antara satu pelanggan dan pelanggan lain.

Dimensi keempat kualitas layanan adalah jaminan (assurance) adalah dimensi yang berhubungan dengan kemampuan perpustakaan dan perilaku staf dalam menanamkan rasa percaya dan keyakinan pada pelanggan. Berdasarkan banyak riset, empat aspek dimensi ini adalah keramahan, kompetensi, kredibilitas dä keamanan.

Dimensi kelima kualitas layanan adalah empati (emphaty). Pelanggan dari kelompok menengah dan atas mempunyai harapan yang tinggi agar perpustakaan penyedia jasa mengenal mereka secara spesifik dan bila perlu mengetahui karakter pribadi mereka lainya.

Dalam memberikan layanan dapat saja terjadi perbedaan persepsi antar pengguna dan penyedia tentang wujud jasa layanan. Hal ini dapat tercermin dari kualitas jasa layanan. Misalnya keluhan pengguna yang disampaikan lewat milis internet dapat menurunkan citra perpustakaan sehingga informasi tadi dapat menjadi masukan untuk bisa diperbaiki.

Tabel : 1

Dimensi Kualitas Layanan

\begin{tabular}{|c|c|c|}
\hline Variabel & Dimensi & Indikator \\
\hline \multirow{5}{*}{$\begin{array}{l}\text { Kualitas } \\
\text { Layanan }\end{array}$} & Bukti fisik & $\begin{array}{ll}\text { Penampilan } & \text { fisik, } \\
\text { nerlatan nersonil }\end{array}$ \\
\hline & Keandalan & $\begin{array}{l}\text { Kemampuan untuk } \\
\text { melaksanakan jasa yang } \\
\text { dijanjikan dengan } \\
\text { terpercaya dan akurat }\end{array}$ \\
\hline & $\begin{array}{l}\text { Daya } \\
\text { Tanggap }\end{array}$ & $\begin{array}{l}\text { Kemapuan untuk } \\
\text { membantu pemakai dan } \\
\text { memberikan jasa dengan } \\
\text { cepat }\end{array}$ \\
\hline & Jaminan & $\begin{array}{lr}\text { Pengetahuan } & \text { dan } \\
\text { Kesopanan } & \text { karyawan, } \\
\text { kemampuan } & \text { mereka } \\
\text { untuk menimbulkan } \\
\text { kepercayaan } \\
\text { keyakinan }\end{array}$ \\
\hline & Empati & $\begin{array}{l}\text { Kesediaan untuk peduli, } \\
\text { memberi perhatian } \\
\text { pribadi kepada pemakai. }\end{array}$ \\
\hline
\end{tabular}

Sumber : Kotler (1994:476)

\section{Pengertian Terbitan Berkala}

Menurut Lasa, HS, (1993:14 ) terbitan berkala merupakan terbitan yang betul - betul telah direncanakan untuk diterbitkan dalam jangka waktu tidak terbatas. Terbitan berkala sebagai salah satu koleksi menyampaikan informasi atau diterbitkan terpisah - pisah dengan judul seragam dan bernomor, terbit menurut jadwal yang sudah ditetapkan untuk waktu yang tidak ditentukan dan biasanya dikelola oleh sekelompok orang.

a. Menurut The Colombia Encyclopedia (2005) menyebutkan bahwa terbitan berkala adalah suatu terbitan dengan berbagai format, memiliki judul yang sama (seragam) meski terbit secara terpisah, biasanya diberi nomor atau tanggal dan terbit dalam jangka waktu yang teratur maupun tidak, serta 
tanpa ada ketentuan kapan terbitan itu akan berhenti terbit, Mengacu pada pengertian di atas yang dimaksud terbitan berkala adalah suatu terbitan yang memiliki format bervariasi, dengan judul sama setiap kala terbit, biasanya diberi nomor dan tanggal, waktu terbit bisa teratur bisa tidak, dan direncanakan untuk terbit dalam jangka waktu tak terbatas, serta biasanya dikelola oleh sekelompok orang. Sedangkan menurut Reitz (2007) :

Periodical : A serial publication with its own distinctive, containing a mix of articles, editorials, reviews, columns, shots stories, poems, or other shots works written by more than one contributor, issued in softcover more than once, generally at regular stated intervals of less than a year, without prior decision as to when the final issue will paper. Allthough each issue is complete in itself, its relationship to proceeding issues is indicated by enumeration, usually issue number and volume number oriented on the front cover. Content is controlled by an editorial board.

Menurut pengertian di atas terbitan berkala adalah suatu terbitan berseri dengan judul tersendiri, berisi tulisan seperti: artikel, editorial, review, kolom, cerpen, puisi, atau tulisan pendek lainnya yang ditulis oleh lebih dari satu orang. Diterbitkan lebih dari satu kali, dengan kover lunak, pada umumnya terbit dengan jangka waktu tertentu yang sudah di tetapkan dalam waktu kurang dari satu tahun.Meski tiap edisinya bersifat tuntas (tidak bersambung), terbitan ini bersifat berkesinambungan yang mana ditunjukkan dengan adanya penomoran berupa volume dan nomor edisi terbitan yang tercantum pada sampul depan luar. Isi terbitan ini diolah oleh seorang ataupun dewan penyunting. Sedangkan menurut definisi The Columbia Encyclopedia, (2005) periodical adalah:

a publication that is issued regularly. It is distinguished from the newspapaer in format in that its pages are smaller and are usually bound, and it is published at weekly, monthly, quarterly, or other intervals, rather than daily. Periodicals range from technical and scholarly journals to illustrated magazines for mass circulation.

Sedangkan pengertian serial dari The Columbia Encyclopedia, (2005)

A publication in any medium issued under the same title in a succession of discreate parts, usually numbered (or dated) and appearing at regular or irregular intervals with no predetermined conclusion.

\section{Metode Penelitian}

Penelitian ini menggunakan metode penelitian deskriptif. Penelitian ini dilakukan terhadap mahasiswa Sekolah Pascasarjana UGM. Subjek penelitian pemakai Perpustakaan Pascasarjana UGM, khususnya pemakai bagian terbitan berkala. Jenis penelitian ini merupakan tipe penelitian deskriptif kuantitatif dengan menggunakan metode survei.

Populasi dalam penelitian ini adalah mahasiswa/pengguna program pasca sarjana UGM yang berkunjung dan mempunyai kartu anggota Perpustakaan Pascasarjana. Berdasarkan data yang diperoleh, populasi ini berjumlah 3000 anggota (yang mendaftar jadi anggota sampai dengan April 2007) terdiri dari mahasiswa yang mengambil Perpustakaan Pascasarjana UGM angkatan akademik 2005 dan 2006 (data diperoleh bagian informasi) sebanyak 100 orang

Metode yang digunakan dalam pengambilan sampel adalah pengambilan sampel aksidental (sample acsidental) merupakan proses pengambilan sampel berdasarkan faktor spontanitas, artinya pemakai yang secara tidak sengaja bertemu dengan peneliti yang sesuai dengan karateristik (ciricirinya), maka orang tersebut dapat digunakan sebagai responden. Hal ini ditujukan agar hasil penelitian benar representative (Rinduwan, 2004: 62)

Dalam penelitian ini variabel yang diukur meliputi satu variabel dengan digunakan variabel tunggal yaitu: persepsi pemakai terhadap kualitas layanan terbitan berkala. 
Tabel 2

Kisi-kisi Variabel dan Indikator

\begin{tabular}{|c|l|l|}
\hline Variabel & \multicolumn{1}{|c|}{ Indikator } & \multicolumn{1}{|c|}{ No.Item } \\
\hline Persepsi & Tangible(bukti fisik) & $1,2,3,4,5,6$ \\
pemakai & Realibility(kehandalan) & $7,8,9,10,11$ \\
terhadap & Responsiveness(Daya & $12,13,14$ \\
kualitas & tanggap) & \\
layanan & Assurance(jaminan) & $15,16,17,18$ \\
terbitan & Empathy(empati) & $19,20,21,22$ \\
berkala & & \\
\hline
\end{tabular}

Metode pengumpulan data dan instrumen menggunakan tiga teknik pengumpulan data yaitu : survei, wawancara, dokumentasi.

Pensekoran atas kuesioner skala Likert yang digunakan dalam penelitian ini merujuk pada lima alternatif jawaban, sebagaimana terlihat di bawah ini:

$\begin{array}{ll}\circ \text { Sangat setuju } & =5 \\ \circ \text { Setuju } & =4 \\ \circ \text { Ragu-ragu } & =3 \\ \circ \text { Tidak setuju } & =2 \\ \circ \text { Sangat tidak setuju } & =1\end{array}$

Tabel 3

Penggolongan Pertanyaan Dalam Kuesioner

\begin{tabular}{|l|l|l|l|}
\hline No & $\begin{array}{l}\text { Indikator Kualitas } \\
\text { Pelayanan }\end{array}$ & No.Pertanyaan & Juml \\
\hline 1 & $\begin{array}{l}\text { Tangible(bukti } \\
\text { langsung) }\end{array}$ & $1,2,3,4,5$ & 5 \\
\hline 2 & Reability(keandalan) & $6,7,8,9,10$ & 5 \\
\hline 3 & $\begin{array}{l}\text { Responsiveness(daya } \\
\text { tanggap) }\end{array}$ & $11,12,13$ & 3 \\
\hline 4 & Asssurance(jaminan) & $14,15,16,17$ & 4 \\
\hline 5 & Empathy(empati) & $18,19,20,21$ & 4 \\
\hline & Jumlah & Jumlah item & 21 \\
\hline
\end{tabular}

Pernyataan persepsi pemakai terhadap kualitas layanan terbitan berkala Perpustakaan Pascasarjana Universitas Gadjah Mada, disusun sebanyak 17 butir pernyataan positif. Penilaian skor terhadap jawaban responden untuk masingmasing butir pernyataan dapat dilihat pada tabel berikut ini.
Tabel 4

Penilaian Butir Skala Persepsi

\begin{tabular}{|l|l|l|}
\hline Pernyataan & Jawaban & Nilai \\
\hline \multirow{3}{*}{ Positif } & Sangat setuju & 5 \\
& Setuju & 4 \\
& Ragu-ragu & 3 \\
& Tidak setuju & 2 \\
& Sangat tidak setuju & 1 \\
\hline
\end{tabular}

Pemberian skor terhadap masing-masing adalah untuk item positif jawaban sangat setuju $=5$, jawaban setuju $=4$, jawaban ragu-ragu $=3$, jawaban tidak setuju $=2$, jawaban sangat tidak setuju $=1$, Setelah angket dilengkapi dengan lembar jawaban, kemudian digandakan untuk diujicobakan.

Didapat nilai interpelasi skor persepsi bahwa bila nilai rata-rata hitung:

$$
\begin{array}{ll}
1,00-1,75 & =\text { Sangat tidak baik } \\
1,76-2,50 & =\text { Tidak baik } \\
2,51-3,25 & =\text { Cukup baik } \\
3,26-4,50 & =\text { Baik } \\
4,51-5,00 & =\text { Sangat Baik }
\end{array}
$$

\section{PEMBAHASAN}

\section{Persepsi Pemakai Terhadap Kualitas Pelayanan Terbitan Berkala}

Kuesioner yang kembali dan telah memenuhi syarat untuk diproses, kemudian diolah dengan cara memberi nomer 1-100. Proses selanjutnya memberikan skor jawaban responden pada masing-masing butir pertanyaan. Selanjutnya kuesioner diolah dengan cara memasukkan jawaban responden ke dalam tabulasi data yang telah disiapkan sesuai dengan dan nomor butir 1 sampai 22 skala persepsi pemakai terhadap kualitas pelayanan Terbitan Berkala Di Perpustakaan UGM. Jika responden sangat setuju akan mendapat skor tertinggi (5) dan jika menjawab setuju akan mendapat skor (4) jika menjawab ragu-ragu akan mendapat skor (3) jika menjawab tidak setuju akan mendapat skor (2) dan jika menjawab sangat tidak setuju akan mendapat skor (1) Setelah melalui proses pengolahan data, maka sebaran nilai persepsi pemakai terhadap kualitas pelayanan terbitan berkala di Perpustakaan Pascasarjana UGM adalah sebagai berikut: 


\section{Variabel Bukti Fisik/Tangibles}

Berikut ini adalah data sebaran pengembalian kuesioner persepsi berdasarkan bukti fisik (tangibles) yang dapat digambarkan dalam enam indikator yaitu sebagai berikut :

1. Sarana temu kembali $(O P A C=$ on line public acces) informasi jurnal cukup efektif

Persepsi pemakai terhadap sarana temu kembali (OPAC $=$ on line public acces) informasi jurnal cukup efektif adalah 24 responden menjawab sangat setuju, 67 responden menjawab setuju, 6 responden menjawab ragu-ragu, 3 responden menjawab tidak setuju dan tidak ada yang menjawab sangat tidak setuju. Dengan demikian dari hasil perhitungan rumus mean dapat diperoleh nilai rata-rata sebesar 4,1 . Berdasarkan nilai rata-rata tersebut dapat dianalisis bahwa persepsi pemakai terhadap sarana temu kembali $(\mathrm{OPAC}=$ on line public acces) informasi jurnal cukup efektif, tergolong sangat baik., terutama untuk jurnal karena pemakai dapat dengan mudah dan cepat menemukan jurnal yang diinginkan.

2. Kebersihan di dalam ruang bagian terbitan berkala sangat menyejukkan

Persepsi pemakai terhadap kebersihan di dalam ruang dan lingkungan bagian jurnal sangat menyejukkan adalah 52 responden menjawab sangat setuju, 47 responden menjawab setuju dan tidak ada yang menjawab ragu-ragu dan. 1 responden menjawab tidak setuju. Dengan demikian dari hasil perhitungan rumus mean dapat diperoleh nilai rata-rata sebesar 4,5. Berdasarkan nilai rata-rata tersebut dapat disimpulkan bahwa persepsi pemakai terhadap kebersihan di dalam ruang dan lingkungan bagian jurnal sangat menyejukkan hal ini tergolong baik. Seperti pendapat pemakai tentang kebersihan toilet di lantai satu:

\section{Ketersediaan judul jurnal benar-benar dibutuhkan pengguna}

Persepsi pengguna terhadap ketersediaan judul jurnal benar-benar dibutuhkan pengguna yaitu 32 responden menjawab sangat setuju, 47 responden menjawab setuju, 14 responden menjawab ragu-ragu, 7 responden menjawab tidak setuju dan tidak ada yang menjawab sangat tidak setuju. Dengan demikian dari hasil perhitungan rumus mean dapat diperoleh nilai rata-rata sebesar 4,04. Berdasarkan nilai rata-rata tersebut dapat dianalisis bahwa persepsi pemakai terhadap ketersediaan judul jurnal benar-benar dibutuhkan pengguna baik

\section{Penampilan petugas bagian terbitan} berkala sangat ( menarik, rapi )

Persepsi pengguna terhadap petugas bagian terbitan berkala sangat (menarik, rapi) adalah 26 responden menjawab sangat setuju, 68 responden menjawab setuju, 6 responden menjawab ragu-ragu dan tidak ada yang menjawab tidak setuju dan sangat tidak setuju. Dengan demikian dari hasil perhitungan rumus mean dapat diperoleh nilai rata-rata sebesar 4,2 . Berdasarkan nilai rata-rata tersebut dapat dianalisis bahwa persepsi pemakai terhadap penampilan petugas bagian terbitan berkala sangat (menarik, rapi) tergolong baik

5. Penerapan teknologi di bagian jurnal meyakinkan dan membantu pemakai

Persepsi pemakai terhadap penerapan teknologi di bagian jurnal meyakinkan dan membantu pemakai yaitu 24 responden menjawab sangat setuju, 55 responden menjawab setuju, 18 responden menjawab ragu-ragu, 2 responden menjawab tidak setuju dan 1 responden menjawab sangat tidak setuju. Dengan demikian dari hasil perhitungan rumus mean dapat diperoleh nilai rata-rata sebesar 4. Berdasarkan nilai rata-rata dapat dianalisis bahwa persepsi pemakai terhadap penerapan teknologi di bagian jurnal meyakinkan dan membantu pemakai tergolong baik

6. Memiliki alat bantu telusur (katalog, indek, artikel) sehingga mempercepat penelusuran.

Persepsi pemakai terhadap kepemilikan alat bantu telusur ( katalog, indeks, artikel ) sehingga mernpercepat penelusuran yaitu 35 responden menjawab sangat setuju, 57 
responden menjawab setuju, 6 responden menjawab ragu-ragu, 2 responden menjawab tidak setuju dan tidak ada yang menjawab sangat tidak setuju. Dengan demikian dari hasil perhitungan rumus mean dapat diperoleh nilai rata-rata sebesar 4,25. Berdasarkan nilai rata-rata tersebut dapat dianalisis bahwa persepsi pemakai terhadap kepemilikan alat bantu telusur (katalog, indeks, artikel) sehingga mempercepat penelusuran tergolong baik

Persepsi pemakai terhadap dimensi bukti fisik/tangibles yang dijabarkan dalam 6 indikator pelayanan dipersepsikan baik, sehingga Perpustakaan Pascasarjana UGM tidak perlu membenahi pelayanan bukti fisik.

\section{Variabel Keandalan/Realibility}

Berikut ini adalah sebaran pengembalian kuesioner berdasarkan variabel keandalan/ realibility yang dapat digambarkan dalam 5 indikator yaitu:

\section{Relevansi koleksi jurnal sesuai dengan cakupannya}

Persepsi pemakai terhadap relevansi jurnal sesuai dengan cakupannya, yaitu 15 responden menjawab sangat setuju, 63 responden menjawab setuju, 20 responden menjawab ragu-ragu, 2 responden menjawab tidak setuju dan tidak ada yang menjawab sangat tidak setuju. Dengan demikian dari hasil perhitungan rumus mean dapat diperoleh nilai rata-rata sebesar 3,91. Berdasarkan nilai rata-rata tersebut dapat dianalisis bahwa persepsi pemakai terhadap relevansi jurnal sesuai dengan cakupannya tergolong baik.

\section{Kemudahan dalam temu kembali jurnal}

Persepsi pemakai terhadap kemudahan dalam temu kembali jurnal adalah 13 responden menjawab sangat setuju, 65 responden menjawab setuju, 20 responden menjawab ragu-ragu, 2 responden menjawab tidak setuju dan tidak ada yang menjawab sangat tidak setuju. Dengan demikian dari hasil perhitungan rumus mean dapat diperoleh nilai rata-rata sebesar 3.89. Berdasarkan niali rata-rata tersebut dapat dianalisis bahwa persepsi pemakai terhadap kemudahan dalam temu kembali jurnal cetak tergolong baik

\section{Kesesuaian pelayanan terbitan berkala dengan jadwal}

Persepsi pemakai terhadap kesesuaian pelayanan terbitan berkala dengan jadwal yang ditetapkan yaitu 14 responden menjawab sangat setuju, 61 responden menjawab setuju, 21 responden menjawab ragu-ragu, 2 responden menjawab tidak setuju, 2 responden menjawab sangat tidak setuju. Dengan demikian dari hasil perhitungan rumus mean dapat diperoleh nilai rata-rata sebesar 3,83 . Berdasarkan nilai rata-rata tersebut dapat dianalisis bahwa persepsi pemakai terhadap kesesuaian pelayanan terbitan berkala dengan jadwal yang ditetapkan tergolong baik.

\section{Kepastian jam pelayanan diinformasikan dengan jelas}

Persepsi pemakai terhadap kepastian jam pelayanan di informasikan dengan jelas adalah 40 responden menjawab sangat setuju, 50 responden menjawab setuju, 8 responden menjawab ragu-ragu, 2 responden menjawab tidak setuju dan tidak ada yang menjawab sangat tidak setuju. Dengan demikian dari hasil perhitungan rumus mean dapat diperoleh nilai rata-rata sebesar 4,28. Berdasarkan nilai rata-rata tersebut dapat di simpulkan bahwa persepsi pemakai terhadap kepastian jam pelayanan di informasikan dengan jelas tergolong baik.

\section{Pelayanan terbitan berkala sesuai dengan harapan pengguna}

Persepsi pemakai terhadap pelayanan terbitan berkala sesuai dengan harapan pengguna yaitu 14 rersponden menjawab sangat setuju, 55 responden menjawab setuju, 26 responden menjawab ragu-ragu, 5 responden menjawab tidak setuju dan tidak ada yang menjawab sangat tidak setuju. Dengan demikian dari hasil perhitungan rumus mean dapat diperoleh nilai rata-rata sebesar 3,78. 
Berdasarkan nilai rata-rata tersebut dapat dianalisis bahwa persepsi pemakai terhadap pelayanan terbitan berkala sesuai dengan harapan pengguna tergolong baik.

Persepsi pemakai terhadap demensi keandalan/realibility yang dijabarkan dalam 5 indikator semua jenis kualitas layanan dipersepsikan baik. Dari keseluruhan skor dari variabel keandalan/realibility diperoleh nilai rata-rata 3,98. Berdasarkan nilai rata-rata tersebut dapat dianalisis bahwa persepsi pemakai terhadap kualitas pelayanan yang berupa demensi keandalan/realibility dapat dikatagorikan baik

\section{Variabel Daya Tanggap/Responsiveness}

Berikut ini adalah data sebaran pengembalian kuesioner persepsi berdasarkan variabel daya tanggap/responsiveness yang dapat dijabarkan dalam 3 indikator yaitu:

1. Pengguna dilayani sesuai dengan aturan dibagian layanan terbitan berkala

Persepsi pemakai terhadap pengguna dilayani sesuai dengan aturan dibagian layanan terbitan berkala adalah 27 responden menjawab sangat setuju, 66 responden menjawab setuju, 6 responden menjawab ragu-ragu, 1 responden menjawab tidak setuju dan tidak ada yang menjawab sangat tidak setuju. Dengan demikia dari hasil perhitungan rumus mean dapat diperoleh nilai rata-rata sebesar $\mathbf{4 , 1 9}$. Berdasarkan nilai rata-rata tersebut dapat dianalisis bahwa persepsi pemakai terhadap pengguna dilayani sesuai dengan aturan dibagian layanan terbitan berkala tergolong baik

2 Petugas memberikan bantuan pengguna dengan tepat kapan layanan jurnal itu dilakukan.

Persepsi pemakai terhadap petugas memberikan bantuan pengguna dengan tepat kapan layanan itu dilakukan adalah 35 responden menjawab sangat setuju, 48 responden menjawab setuju, 17 responden menjawab ragu-ragu dan tidak ada yang menjawab tidak setuju dan sangat tidak setuju. Dengan demikian dari hasil perhitungan rumus mean dapat diperoleh nilai rata-rata sebesar 4,18 . Berdasarkan nilai rata-rata tersebut dapat dianalisis bahwa persepsi pemakai terhadap petugas memberikan bantuan dengan tepat kapan layanan itu dilakukan tergolong baik

3 Kecepatan layanan dalam mencarikan jurnal kepada pengguna sangat cepat.

Persepsi pemakai terhadap kecepatan layanan dalam mencarikan jurnal kepada pengguna sangat cepat adalah 23 responden menjawab sangat setuju, 53 responden menjawab setuju, 21 responden menjawab ragu-ragu, 3 respopnden menjawab tidak setuju dan tidak ada yang menjawab sangat tidak setuju. Dengan demikian dari hasil perhitungan rumus mean dapat diperoleh nilai rata-rata sebesar 3,96. Berdasarkan nilai rata-rata tersebut dapat dianalisis bahwa persepsi pemakai terhadap kecepatan layanan dalam mencarikan jurnal kepada pengguna sangat cepat tergolong baik

Persepsi pemakai terhadap dimensi daya tanggap/responsiveness terhadap semua jenis kutipan layanan dipersepsikan baik.

\section{Variabel Jaminan/Assurance}

Berikut ini adalah data sebaran pengembalian kuesioner persepsi berdasarkan variabel jaminan/assurance yang dapat dijabarkan dalam 4 indikator yaitu:

\section{Jumlah Staf (pelayanan informasi jurnal) sudah memadai}

Persepsi pemakai terhadap jumlah Staf (pelayanan informasi jurnal) sudah memadai yaitu 12 responden menjawab sangat setuju, 59 responden menjawab setuju, 15 responden menjawab ragu-ragu, 13 responden menjawab tidak setuju, 1 responden menjawab sangat tidak setuju. Dengan demikian dari hasil perhitungan rumus mean dapat diperoleh nilai rata-rata sebesar 3,68. Berdasarkan nilai rata-rata tersebut dapat dianalisis bahwa pemakai terhadap jumlah staf (pelayanan informasi jurnal) sudah memadai tergolong baik

\section{Petugas siap untuk membantu mencarikan jurnal sesuai keinginan pengguna}

Persepsi pemakai terhadap petugas siap untuk membantu download jurnal sesuai keinginan pengguna adalah 24 responden menjawab sangat setuju, 51 responden menjawab setuju, 21 responden menjawab ragu-ragu, 4 
responden menjawab tidak setuju dan tidak ada menjawab sangat tidak setuju. Dengan demikian dari hasil perhitungan rumus mean dapat diperoleh nilai rata-rata sebesar 3,95 Berdasarkan nilai rata-rata tersebut dapat dianalisis bahwa persepsi pemakai terhadap petugas siap membantu mencarikan jurnal sesuai keinginan pengguna tergolong baik

\section{Ketrampilan staf dalam mencarikan pangkalan data terbitan berkala}

Persepsi pemakai terhadap ketrampilan staf dalam mencarikan pangkalan data terbitan berkala adalah 20 responden menjawab sangat setuju, 65 responden menjawab setuju, 11 responden menjawab ragu-ragu, 4 responden menjawab tidak setuju dan tidak ada yang menjawab sangat tidak setuju. Dengan demikian dari hasil perhitungan rumus mean dapat diperoleh nilai rata-rata sebesar 4,01 . Berdasarkan nilai rata-rata tersebut dapat dianalisis bahwa persepsi pemakai terhadap ketrampilan staf dalam mencarikan pangkalan data terbitan berkala tergolong baik

\section{Apa yang dicari/dibutuhkan selalu terpenuhi}

Persepsi pemakai terhadap apa yang dicari/dibutuhkan selalu terpenuhi adalah 7 responden menjawab sangat setuju, 34 responden menjawab setuju, 40 responden menjawab raguragu, 14 responden menjawab tidak setuju, 5 respomden menjawab sangat tidak setuju. Dengan demikian dari hasil perhitungan rumus mean dapat diperoleh nilai rata-rata sebesar 3,24. Berdasarkan nilai rata-rata dapat dianalisis bahwa persepsi pemakai terhadap apa yang dicari/dibutuhkan selalu terpenuhi tergolong cukup baik.

Persepsi pemakai terhadap dimensi jaminan/assurance yang dijabarkan dalam 4 indikator dimana 3 jenis layanan dipersepsikan baik dan 1 indikator dipersepsikan cukup baik. Layanan yang dipersepsikan cukup baik adalah apa yang dicari/dibutuhkan selalu terpenuhi, dikarenakan sarana temu kembalinya belum efektif. Untuk Perpustakaan Pascasarjana Universitas Gadjah Mada sebaiknya mempertimbangkan kebijakan yang menangani temu kembali informasi agar tujuannnya bisa lebih baik. Namun dari skor dari variabel jaminan/assurance diperoleh nilai rata-rata 3,72. Berdasarkan nilai rata-rata tersebut dapat dianalisis bahwa persepsi pemakai terhadap pelayanan jaminan/assurance dapat dikatagorikan baik.

\section{Variabel Empati/Empaty}

Berikut ini adalah data sebaran pengembalian kuesioner persepsi pemakai berdasarkan variabel empati/empaty yang dapat dijabarkan dalam 4 indikator yaitu:

\section{Cara petugas, bagian layanan terbitan berkala berbicara dengan pengguna bersikap santun, ramah}

Persepsi pengguna terhadap cara petugas bagian layanan terbitan berkala berbicara dengan pengguna bersikap santun, ramah. adalah 31 responden menjawab sangat setuju, 64 responden menjawab setuju, 5 responden menjawab ragu-ragu dan tidak menjawab tidak setuju dan sangat tidak setuju. Dengan demikian dari perhitungan rumus mean dapat diperoleh nilai rata-rata sebesar 4,26. Berdasarkan nilai rata-rata tersebut dapat dianalisis bahwa persepsi pemakai terhadap cara petugas, bagian layanan terbitan berkala berbicara dengan pengguna bersikap santun,ramah tergolong baik

2. Cara petugas terbitan berkala dalam melaksanakan pelayanan memuaskan pengguna.

Persepsi pengguna terhadap cara petugas terbitan berkala dalam melaksanakan pelayanan memuaskan pengguna adalah 28 responden menjawab sangat setuju, 58 responden menjawab setuju, 13 responden menjawab ragu-ragu, 1 responden menjawab tidak setuju dan tidak ada yang menjawab sangat tidak setuju. Dengan demikian dari perhitungan rumus mean dapat diperoleh nilai rata-rata sebesar 4,13 . Berdasarkan nilai ratarata tersebut dapat dianalisis bahwa persepsi pemakai tehadap cara petugas terbitan berkala dalam melaksanakan pelayanan memuaskan pengguna tergolong baik

\section{Petugas sudah memahami kenyamanan yang dibutuhkan pengguna}


Persepsi pemakai terhadap petugas sudah memahami kenyamanan yang dibutuhkan pengguna adalah 24 responden menjawab sangat setuju, 56 responden menjawab setuju, 19 responden menjawab ragu-ragu, 1 responden menjawab tidak setuju dan tidak ada yang menjawab sangat tidak setuju. Dengan demikian dari perhitungan rumus mean dapat diperoleh nilai rata-rata sebesar 4,03. Berdasarkan nilai rata-rata tersebut dapat dianalisis bahwa persepsi pemakai terhadap petugas sudah memahami kenyamanan yang dibutuhkan pengguna tergolong baik

\section{Memberikan layanan tanpa membedakan status pengguna}

Persepsi pemakai terhadap pemberian layanan tanpa membedakan status pengguna adalah 40 responden menjawab sangat setuju, 52 responden menjawab setuju, 7 responden menjawab ragu-ragu, 1 responden menjawab tidak setuju dan tidak ada menjawab sangat tidak setuju. Dengan demikian dari hasil perhitungan rumus mean dapat diperoleh nilai rata-rata sebesar 4,31. Berdasarkan nilai ratarata tersebut dapat dianalisis bahwa persepsi pemakai terhadap pemberian layanan tanpa membedakan status pengguna tergolong baik.

Persepsi pemakai terhadap dimensi empati/empaty yang dijabarkan dalam 4 indikator dimana semua layanan dipersepsikan baik. Dari keseluruhan skor dari variabel empati/empaty diperoleh nilai rata-rata 4,18 . Berdasarkan nilai rata-rata tersebut dapat dianalisis bahwa persepsi pengguna terhadap pelayanan yang berupa empati/empaty dapat dikatagorikan baik.

Dari segi variabel bukti fisik/tangible, kehandalan/realibility, daya tanggap/ responsivenes dan empati/empaty walaupun semua indikatornya rata-rata baik, tapi Perpustakaan Pascasarjana UGM sebaiknya lebih banyak meningkatkan pelayanan agar kualitas pelayanan yang diberikan semakin baik, salah satu faktor elemen dasar kualitas pelayanan perpustakaan adalah kualitas meliputi usaha untuk memenuhi atau melebihi harapan atau segala sesuatu yang memuaskan pelanggan sesuai dengan persyaratan kebutuhan. Adapun ciri-ciri yang ada dalam kualitas antara lain: (1) ketepatan waktu pelayanan, yang meliputi waktu tunggu dan waktu proses, (2) akurasi layanan, yang meliputi bebas dari kesalahan-kesalahan. (3) kesopanan dan keramahan dalam memberikan pelayanan (4) kemudahan mendapatkan pelayanan misalnya banyaknya petugas yang melayani dan banyaknya fasilitas pendukung seperti komputer; (5) kenyamanan dalam memperoleh pelayanan, berkaitan lokasi ruang, tempat pelayanan, ketersedian informasi. (6) atribut pendukung pelayanan lainnya seperti ruang tunggu ber AC kebersihan. (Santosa: 2007:5)

Kualitas pelayanan perpustakaan tergantung penuh kepada ketrampilan dan profesionalisme. Para pemakai menyadari bahwa pemberi pelayanan dan para petugas memiliki pengetahuan dan ketrampilan yang diperlukan untuk memecahkan masalah secara profesional. Untuk terciptanya staf perpustakaan Pascasarjana yang berkualitas diperlukan pengembangan sikap dan perilaku yang baik, sehingga akan dirasakan pengguna bahwa petugas pelayanan memperhatikan dan tertarik untuk memecahkan masalah penggunasecara spontan disamping dipersiapkan sistem akses kepada pelayanan sesuai dengan permintaan pemakai.

Berikut ini adalah rata-rata keseluruhan kualitas pelayanan terbitan berkala berdasarkan 5 demensi kualitas serqual menurut Zeithmal, Parasuraman dkk pada pelayan terbitan berkala di perpustakaan Pascasarjana Universitas Gadjah Mada

Berdasarkan persepsi pemakai terhadap kualitas pelayanan Terbitan Berkala dinilai dari 5 dimensi yang masing-masing menggambarkan nilai persepsi dikategorikan dengan skala interval sebagai berikut:

1. Untuk dimensi bukti fisik/tangibles, nilai rata-rata persepsi pemakai adalah 4,18 , sehingga berdasarkan nilai rata-rata tersebut tergolong baik.

2. Untuk dimensi kehandalan/reliability, nilai rata-rata persepsi pemakai adalah 3,98, sehingga berdasarkan nilai rata-rata tersebut tergolong baik. 
3. Untuk dimensi daya tanggap/responsive, nilai rata-rata persepsi pemakai adalah 4,11 sehingga berdasarkan nilai rata-rata tersebut tergolong baik.

4. Untuk dimensi Jaminan/assurance, nilai ratarata persepsi pemakai adalah 3,72 sehinga berdasarkan nilai rata-rata tersebut tergolong baik

5. Untuk dimensi empati/empaty, nilai rata-rata persepsi pemakai adalah 4,18 sehingga berdasarkan nilai rata-rata tersebut tergolong baik.

6. Nilai rata-rata persepsi pemakai seluruhnya termasuk baik, dengan nilai rata-rata 4,03

Melihat dari hasil analisa diatas kualitas layanan yang diberikan Perpustakaan Pascasarjana UGM bagian terbitan berkala sudah sesuai dengan persepsi pemakai. Hal ini dapat dilihat dari rata-rata penafsiran persepsi pemakai terhadap pelayanan menunjukan 5 dimensi atau variabel kualitas sebesar 4,03 Dengan demikian persepsi pemakai terhadap kualitas pelayanan sudah baik.

\section{Kesimpulan}

Berdasarkan hasil analisis data dan uraian pada pembahasan bab-bab sebelumnya, maka dalam penelitian ini dapat ditarik kesimpulan sebagai berikut:

1. Nilai rata-rata secara keseluruhan didapat 4,03 sehingga dapat dikatagorikan bahwa persepsi pemakai terhadap kualitas pelayanan terbitan berkala di Perpustakaan Pascasarjana Universitas Gadjah Mada tergolong baik. Dari 5 dimensi kualitas layanan menjadi 22 buah pertanyaan yaitu: dimensi fisik nilai rata-rata 4,18 , dimensi kehandalan nilai ratarata 3,98, dimensi daya tanggap nilai rata-rata 4,11 , dimensi jaminan nilai rata-rata 3,72 , dimensi empati nilai rata-rata 4,18.

2. Dari lima dimensi yang menjadi persepsi pemakai dalam memilih layanan terbitan berkala di Perpustakaan Pascasarjana Universitas Gadjah Mada yang menjadi pertimbangan karena tergolong paling rendah yaitu: dimensi kehandalan dengan nilai ratarata 3,98 masih termasuk tergolong baik, maka dimensi jaminan dengan nilai rata-rata 3,72 tergolong baik

3. Dari tiga dimensi yang dipersepsikan pemakai dalam memilih layanan terbitan berkala di Perpustakaan Pascasarjana Universitas Gadjah Mada dapat memberikan sumbangan dalam pengelolaan layanan terbitan berkala yang akan datang.

\section{DAFTAR PUSTAKA}

Arikunto, Suharsimi. 2006. Prosedur Penelitian; suatu pendekatan praktek.

Jakarta : Rineka Cipta.

Dewi, Tristiana Candra, 1999. Pemanfaatan Perpustakaan Perguruan Tinggi Evaluasi terhadap keterpakaian majalah ilmiah. Yogyakarta: Universitas Gadjah Mada.

Diani, Rizki. 1997. Terbitan berkala di Perpustakaan The British Council.Yogyakarta: Fisipol UGM.

Djunaidi. 2006. Analisis Kepuasan Pelanggan Fuzzy service Quality dalam upaya peningkatan Kualitas Pelayanan http: // eprints.UMS.ac.id/83/01/jti.apr.06.05pdf 12:40.

Duriyanto. 2004. Brand Equity ten strategy memimpin pasar. Jakarta: PT Gramedia Pustaka Utama.

Hadisugito. 2007. fadla.or.id/2005/12/11/mengukurkepuasan-pelanggan/ - 27k akses 18 Januari 2007 8:52 am.

Lasa,HS. 1993. Pengelolaan Terbitan Berkala. Yogyakarta: Kanisius. , 1991. Terbitan Berkala dan Bahan Khusus. Yogyakarta: Diklat Pusdokinfo.

Mansjur. 2000. Mengenal Bahan Pustaka dan cara mengelolanya. Bogor : Badan Penelitian dan Pengembangan Pertanian.

Masruri, Anis. 2004. "Kualitas Pelayanan Perpustakaan (studi kasus pada perpustakaan IAIN Sunan Kalijaga Yogyakarta) dalam Berkala Ilmu Perpustakaan dan Informasi UPU Perpuatakaan UGM Vol1(2) hal 5

Mardyantiwi, Ignatia. 2003. "Sikap mahasiswa terhadap fasilitas dan pelayanan perpustakaan Universitas Atma Jaya Yogyakarta" dalam Berkala Ilmu Perpustakaan dan Informasi UPU Perpustakaan UGM Vol 1(2) 2003 hal 19. 
Nasution, MN. 2001. Manajemen mutu terpadu (Total Quality management.) Jakarta : Ghalia Indonesia.

Nawawi, Hadari. 1998. Metode Penelitian bidang sosial Yogyakarta: Gadjah Mada University Press.

Parasuraman, Zeithmal. 1988. "Serqual: MultipleItem Scale Measuring Customer Perception of Service," Journal of Retailing, spring 1988 pp. $12-40$.

Ridwan. 2006. Metode dan Teknik Menyusun Tesis. Bandung: Alfabeta.

Qalyubi, Syihabuddin. 2003. Dasar - dasar Ilmu Perpustakaan dan Informasi. Yogyakarta : IAIN Sunan Kalijaga Yogyakarta.

Reitz, Joan M. 2007. ODLIS - Online Dictionary for Library and Information Science. http://lu.com/odlis/odlis m.cfm, 2 Februari pk 7:46 am.

Riyanto, Agus. 2001. Analisis Kualitas Jasa Pelayanan Perpustakaan Pasca Sarjana Universitas Gadjah Mada Yogyakarta Dalam Berkala Ilmu Perpsutakaan dan Informasi Vol 2(1) hal 16.

Rosyadi, Imron. 2002. "Antisipasi Perpustakaan Terhadap Perilaku Pemakai". Makalah Seminar Perubahan Perilaku Pemakai. 2 Maret 2002. Yogyakarta:Universitas Gadjah Mada.

Santoso, Heri. 2007. "Peningkatan Kualitas layanan Perpustakaan yang berorientasi pada Kepuasan Pemakai" Media Pustakawan Vol 14(1) hal 25.

Sulistya-Basuki. 1992. Teknik dan Jasa Dokumentasi. Jakarta: PT Gramedia Pustaka Utama.

Simamora, Bilson. 2004. Panduan Riset Perilaku Konsumen. Jakarta: Gramedia Pustaka Utama.

Sugiyono. 2005. Memahami Penelitian Kualitatif. Bandung: Alfabeta.

Supriadi. 2004. Analisis Kualitas layanan perpustakaan pada perpustakaan Universitas Jember. Dalam Berkala Ilmu Perpustakaan dan Informasi vol 2(1) hal 22.

Supranto, J. 1997. Pengukuran Tingkat Kepuasan Pelanggan untuk menaikkan pangsa Pasar. Jakarta : Rineka Cipta.

Tjiptono, Fandi. 1997. Prinsip - prinsip Total Quality Service Yogyakarta: Andi Offset. Yogyakarta : Andi Offset.
1996 Strategy Bisnis dan manajemen. Yogyakarta : Andy Ofset.

1997. Strategy Pemasaran. Yogyakarta : Andy Offset.

Walgito, Bimo.1999. Psikologi Sosial (Suatu Pengantar) Yogyakarta : Andi Ofset. 